\title{
Ketika Pak Pos Tidak Hanya Mengantar Surat: Jasa Pengiriman Pos Indonesia di Mata Pedagang Online*
}

\author{
Selma Soraya Viollina \\ Alumni Departemen Antropologi, Universitas Gadjah Mada \\ Email: selmasoraya11@gmail.com
}

\begin{abstract}
This article aims to describe the views of online merchants on goods delivery services in the current e-commerce era, especially the delivery service owned by PT Pos Indonesia, which previously focused on delivering correspondence. The ethnographic method was used to collect qualitative data through observation and in-depth interviews with five informants who were online merchants, in which they were selected using a purposive sampling technique. The results show that online merchants have diverse experiences while using Pos Indonesia delivery services, both for trading needs and personal delivery needs. From this experience, there are three main points that have helped shape the views of online merchants towards Indonesian Post delivery services, namely 1) Pos Indonesia as a State-Owned Enterprises (BUMN), 2) low shipping cost, 3) Pos Indonesian in adapting to the times.
\end{abstract}

Keywords: e-commerce, online merchants, delivery service, Pos Indonesia

\begin{abstract}
Abstrak
Artikel ini bertujuan untuk mendeskripsikan pandangan pedagang online terhadap jasa pengiriman barang di era e-commerce saat ini khususnya jasa pengiriman milik PT Pos Indonesia yang sebelumnya memiliki fokus kerja dalam pengantaran surat menyurat. Metode etnografi dilakukan untuk pengumpulan data kualitatif melalui observasi serta wawancara mendalam terhadap lima informan yang merupakan pedagang online, di mana kelima informan tersebut dipilih dengan menggunakan teknik purposive sampling. Hasil penelitian menunjukkan bahwa pedagang online memiliki pengalaman yang beragam selama menggunakan jasa pengiriman Pos Indonesia, baik untuk kebutuhan berdagang maupun kebutuhan pengiriman pribadi. Dari pengalaman tersebut, terdapat tiga poin utama yang turut membentuk pandangan pedagang online terhadap jasa pengiriman Pos Indonesia, yaitu 1) Pos Indonesia sebagai BUMN, 2) tarif ongkos kirim yang murah, 3) Pos Indonesia dalam
\end{abstract}

Artikel ini berangkat dari penelitian skripsi yang didanai oleh PT Pos Indonesia 
beradaptasi dengan perkembangan zaman.

Kata Kunci: e-commerce, pedagang online, jasa pengiriman, Pos Indonesia

\section{Kebangkitan Jasa Pengiriman di Era E-commerce}

Pada tahun 2012, Boston Consulting Group merilis sebuah penelitian yang menunjukkan bahwa peningkatan jumlah pengguna internet di suatu negara berdampak langsung kepada pertumbuhan ekonomi, efisiensi, dan produktivitas dari negara tersebut. Penelitian ini selaras dengan cita-cita Indonesia yaitu mewujudkan era ekonomi digital dengan melakukan transformasi digital melalui pembukaan akses internet hingga tingkat desa, penambah kecepatan internet, serta mengembangkan industri teknologi dan informasi.

Penelitian berjudul The Opportunity of Indonesia yang diterbitkan TEMASEK ${ }^{1}$ bekerjasama dengan Google menyebutkan Indonesia diprediksi akan menjadi raja dalam pertumbuhan e-commerce di Asia Tenggara pada tahun 2025. Demi mewujudkan mimpi tersebut, pemerintah Indonesia mulai bergegas mempersiapkan segala keperluan, salah satunya dengan merangkul Usaha Mikro, Kecil, dan Menengah (UMKM) agar mengembangkan usaha mereka secara online.

E-commerce yang begitu disambut baik di Indonesia turut mempengaruhi industriindustri pendukungnya, salah satunya industri logistik. Yukki Nugrahawan Hanafi, selaku Ketua Umum DPP Asosiasi Logistik dan Forwarder Indonesia (ALFI) menyatakan bahwa pesatnya pertumbuhan e-commerce di Indonesia berimbas langsung pada industri logistik secara keseluruhan. Praktik e-commerce tidak dapat dilepaskan dari aktivitas di dalamnya yaitu aktivitas jual beli yang dilakukan di dunia maya, di mana kemudian pedagang dan pembeli melakukan pertukaran barang sesuai dengan yang dibutuhkan tanpa melakukan tatap muka atau bertemu secara langsung (Bell 2002; Turban et al. 2017).

Berdagang secara online melalui e-commerce memungkinkan untuk terciptanya pasar yang tidak terikat oleh teritori. Sebagai perantara, jasa pengiriman menjadi solusi agar barang bisa sampai ke tangan pembeli dari tangan pedagang. Praktik jual beli secara konvensional umumnya dilakukan pada tempat yang telah disediakan seperti pasar tradisional dan modern, bazaar, atau pedagang yang berkeliling menjajakan dagangannya. Pada praktik jual beli secara online, pasar pun tercipta secara virtual dan praktik jual beli dilakukan di "tempat" yang tersedia, seperti e-marketplace dan media sosial (Miller 2016; Turban et al. 2016).

Menurut Turban et al. e-commerce terbagi menjadi dua jenis yaitu pure e-commerce dan partial e-commerce $(2017,8)$. Penggolongan ini berdasarkan pada bagaimana proses jual beli tersebut berlangsung yang dapat dilihat dari tiga hal yaitu, 1) ordering es payment, 2) order fulfillment, 3) delivery to customer. Praktik jual beli online dapat dikategorikan sebagai pure e-commerce jika ketiga proses di atas dilakukan secara virtual atau dengan kata lain, tidak ada proses secara fisik yang terlibat. Sebagai contoh, seseorang yang membeli

$1 \quad$ TEMASEK merupakan perusahaan induk milik pemerintah Singapura yang memegang investasi negara tersebut. 
tiket pesawat melalui platform Tiket.com, melakukan pembayaran melalui virtual account, kemudian pihak maskapai atau Tiket.com memberikan pembeli tersebut melalui e-mail dalam bentuk pdf dan pembeli menunjukkan tiketnya melalui telepon genggam ketika boarding. Baik pedagang - dalam contoh kasus di atas adalah maskapai penerbangan - dan pembeli sama-sama tidak bertemu dan tidak ada benda atau proses yang berbentuk fisik yang dilakukan atau sepenuhnya dilakukan secara virtual. Dalam pure e-commerce peran jaringan internet sangat vital karena proses jual beli - mulai dari pembelian hingga proses pengiriman - sangat bergantung kepada kekuatan jaringan internet (Turban et al. 2017).

Berbeda dengan pure e-commerce yang sangat bergantung pada kekuatan jaringan internet, dalam partial e-commerce peran jasa pengiriman menjadi tumpuan utama. Partial e-commerce merupakan praktik jual beli di mana di antara prosesnya terdapat aktivitas yang melibatkan fisik yang dilakukan dan yang paling sering kita temui adalah proses pengiriman barang. Jasa pengiriman merupakan motor penggerak utama dalam praktik jual beli online, sebab pada dasarnya praktik jual beli online hanya menghapus batasanbatasan antara pedagang pembeli - salah satunya jarak - namun tidak menghapuskan bukti dari transaksi jual beli tersebut (Ehmke dan Mattfeld 2012, 623). Sebagai contoh, seorang pria yang membeli sepatu olahraga di platform Zalora.co.id. Pria tersebut memilih sepatu secara online, melakukan pembayaran lewat $m$-banking, namun sepatu tidak mungkin muncul sendirinya dari layar gawai. Pedagang online yang menjajakan dagangan sepatunya di Zalora.co.id harus mengirimkan sepatu yang dipesan pria tersebut ke alamat yang dicantumkan pada platform. Di sini, peran jasa pengiriman adalah mengantarkan barang dari tangan pedagang ke tangan pembeli.

Salah satu penyedia jasa pengiriman barang adalah Pos Indonesia. Sejak tahun 1877, Pos di Indonesia yang kini menjadi Pos Indonesia sudah memiliki tugas untuk pengantaran barang antar kota. Kondisi ini tentu saja menguntungkan bagi Pos Indonesia menjadi pemain di dunia e-commerce, khususnya sebagai perantara pengiriman barang dari pedagang dan pembeli yang bertransaksi secara online. Baik pedagang dan pembeli dapat menggunakan jasa pengiriman barang dari Pos Indonesia untuk mengantarkan barang yang dijual serta dibeli tanpa bertemu langsung. Meski sudah ratusan tahun bergerak di bidang ekspedisi dan logistik, Pos Indonesia tentu bukan satu-satunya perusahaan jasa pengiriman yang tersedia sebagai pilihan. Banyak pilihan jasa pengiriman yang dapat digunakan sebagai perantara pengantaran barang dalam jual beli online, seperti JNE, TIKI, J\&T, SiCepat, hingga milik luar negeri seperti DHL, FedEx, dan Aramex. Masing-masing menawarkan layanan serta kualitas yang berbeda-beda dan bersaing untuk menjadi pilihan bagi masyarakat.

Dari banyaknya pilihan jasa pengiriman yang tersedia, Pos Indonesia tentu masih menjadi salah satu pilihan masyarakat terbukti dari eksistensinya hingga saat ini. Meski begitu, menarik untuk diketahui lebih lanjut bagaimana Pos Indonesia kini dipandang oleh para pelaku e-commerce, salah satunya pedagang online yang dalam pekerjaannya bergantung pada penyedia jasa pengiriman barang? Masing-masing pedagang online tentu memiliki hal yang melatarbelakangi keputusan mereka dalam memilih jasa pengiriman apa yang akan mereka gunakan. Dalam artikel ini, saya akan membahas bagaimana pandangan para pedagang online mempengaruhi keputusan mereka dalam menggunakan jasa pengiriman barang oleh Pos Indonesia. 


\section{Pos Indonesia di Era E-commerce: Pak Pos yang Hanya Mengantar Surat}

Salah satu jasa pengiriman yang ada di Indonesia adalah Pos Indonesia. Jasa pengiriman yang dikelola oleh negara di bawah naungan Badan Usaha Milik Negara (BUMN) ini telah memiliki hampir seratus persen cabang hingga tingkat kecamatan di seluruh Indonesia. Kantor Pos Indonesia pertama didirikan pada tahun 1746 di Batavia (sekarang Jakarta) dengan tujuan menjadi penjamin keamanan surat-surat milik penduduk. Seabad kemudian, Pos Indonesia di bawah pemerintahan Belanda ditunjuk untuk melayani pengiriman surat dan barang baik dalam negeri maupun mancanegara. Sejarahnya yang panjang dalam dunia logistik membuat Pos Indonesia saat ini menjadi satu-satunya jasa pengiriman di Indonesia yang memiliki cabang serta melayani pengiriman hingga tingkat kecamatan sehingga cakupan pengiriman barangnya dapat dikatakan yang paling luas jika dibandingkan dengan jasa pengiriman lainnya. Pos Indonesia pada awalnya lebih dikenal sebagai perusahaan milik negara yang berurusan dengan surat menyurat kini mulai bertransformasi dengan memfokuskan praktek kerjanya kepada pengiriman paket dan barang. Target pasar Pos Indonesia pun turut mengalami perubahan, bukan lagi sahabat pena yang saling bertukar kabar melalui surat atau kerabat beda negara yang bertukar kartu pos untuk dikoleksi, melainkan para pelaku jual beli online yang melakukan transaksi tanpa bertatap muka.

Sebagai bentuk adaptasinya dengan era e-commerce, pada tahun 2019 lalu, Pos Indonesia memunculkan layanan bernama Q-Comm, yaitu layanan khusus pedagang online yang memiliki tiga keunggulan yaitu, 1) kurir dapat mengambil paket ke lokasi pedagang online tanpa dipungut biaya, 2) resi otomatis, dan 3) cash on delivery. Bukan kali ini saja Pos Indonesia berinovasi agar mampu bersaing di era e-commerce ini. Sebelumnya pada tahun 2016 Pos Indonesia telah lebih dulu menggandeng Lazada, salah satu pemain e-commerce terbesar di Indonesia, untuk berkolaborasi di mana para konsumen Lazada diberi kemudahan untuk melakukan pengembalian barang jika menggunakan jasa Pos Indonesia.

Menjadi satu-satunya jasa pengiriman yang dikelola negara serta sepak terjangnya dalam dunia antar-mengantar seharusnya menjadi poin lebih bagi Pos Indonesia untuk bersaing dengan jasa pengiriman lainnya. Meski begitu, diskusi terkait Pos Indonesia tidak dapat dilepaskan dari statusnya sebagai BUMN, di mana perusahaan-perusahaan yang dikelola oleh pemerintah ini sudah lama dipandang lambat serta tidak efisien dalam bekerja dan melayani masyarakat jika dibandingkan dengan perusahaan milik non-pemerintah. (Priambodo 2004). Label yang terlanjur lama melekat pada BUMN ini seolah membuat Pos Indonesia bekerja lebih ekstra, beradaptasi dengan dunia e-commerce dengan citra yang buruk yang terlanjur melekat.

Kondisi ini yang kemudian memunculkan rasa penasaran saya, bagaimana Pos Indonesia kemudian dipandang oleh para pelaku e-commerce di tengah citra buruk yang pernah melekat pada BUMN? Apakah Pos Indonesia masih menjadi pilihan di antara banyaknya perusahaan-perusahaan jasa pengiriman yang lahir ketika e-commerce sudah menjadi bagian dari kehidupan masyarakat? Sebab, reputasi jasa pengiriman turut andil juga dalam menentukan reputasi suatu toko online. Pengalaman buruk yang disebabkan oleh kinerja dan performa jasa pengiriman yang kurang baik akan berdampak pada toko online yang dianggap tidak kompeten dalam melayani pelanggannya sehingga pelanggan 
cenderung tidak merekomendasikan toko online tersebut (Ahmad 2002). Hal ini membuat pemilihan jasa pengiriman menjadi hal penting karena tentu tidak ada toko online ingin reputasinya dikompromikan karena jasa pengiriman yang tidak kompeten.

\section{Untung Rugi Pos Indonesia sebagai Milik Negara}

Kepemilikan Pos Indonesia sebagai Badan Usaha milik pemerintah sudah menjadi bonus tersendiri bagi Pos Indonesia guna memantaskan diri untuk bersaing dengan jasa pengiriman lainnya. Hal ini diakui oleh Glen yang telah menggunakan jasa pengiriman Pos Indonesia sejak pertama kali menjadi Online Plant Seller (OPS). Tanaman merupakan salah satu jenis barang yang harus dikarantina guna mengetahui apakah tanaman tersebut mengandung bakteri atau senyawa lain yang dapat membahayakan tanaman lain. Berdasarkan kebijakan tersebut, Glen selalu membawa tanamannya ke Balai Karantina Pertanian Kelas II (BKPKII) sebelum dikirimkan ke pelanggan di luar kota. Beberapa Cabang Besar Pos Indonesia sudah terintegrasi dengan BKPKII, salah satunya Pos Indonesia yang menjadi langganan Glen yaitu Pos Indonesia Jalan P Senopati Yogyakarta sehingga Glen tidak perlu mondar-mandir mengurus tanaman yang akan dikirimnya. Namun menurut Glen, meski sudah terintegrasi dengan BKPKII, Pos Indonesia belum serius dalam menangani jenis kiriman yang memang membutuhkan sertifikat karantina. Hal ini menurut Glen dapat dilihat dari masih banyak kawan-kawannya yang juga bekerja sebagai OPS yang tidak melakukan proses legal dalam pengiriman tanaman. Selain itu, Glen juga tidak jarang mendapati tanamannya hancur ketika sampai di tangan pelanggan khususnya pelanggan di luar Jawa meski pada paketnya sudah tertera keterangan berisi tanaman hidup. Kondisi ini tentu merugikan bagi Glen karena harganya harus bersaing dengan OPS yang tidak melakukan karantina tanaman. Selain itu, ia juga mendapat penilaian yang buruk dari pelanggan yang disebabkan oleh kelalaian pihak ketiga.

Berdasarkan pengalaman Glen, kinerja instansi pemerintah seringkali kurang serius dan cenderung abai dalam bekerja. Glen juga seringkali menemui masalah dengan BKPKII ketika hendak melakukan proses karantina. Misalnya, pegawai seringkali telat datang dan mengulur waktu pemeriksaan tanaman yang menyebabkan keterlambatan pengiriman tanaman kepada pelanggan. Keadaan ini kemudian Glen siasati melalui kerjasama dengan jasa pengiriman swasta yang menurutnya memiliki kredibilitas dan etos kerja yang lebih baik. Jika tidak ada permintaan khusus dari pelanggannya untuk menggunakan jasa Pos Indonesia, Glen memilih menggunakan jasa pengiriman milik swasta.

Sama halnya dengan Glen, Reza memilih menggunakan jasa pengiriman swasta jika tidak ada request khusus dari pelanggannya. Hal ini dilatarbelakangi oleh status Pos Indonesia sebagai perusahaan milik negara yang menurut Reza turut mempengaruhi hadirnya stigma negatif terhadap Pos Indonesia. Reza yang menjual jam tangan buatan Swedia ini merasa bahwa jam tangannya bukanlah barang murahan. Hal ini membuat Reza sangat peduli terhadap reputasi toko online-nya. Baginya, jika reputasi tokonya bagus maka orang akan yakin bahwa barang yang dijualnya merupakan barang original. Sebaliknya, jika reputasi toko online-nya jelek, orang akan menilai bahwa ia menjual jam tangan palsu. Reputasi ini ia bangun tidak hanya dari getolnya Reza mengunggah testimonial dari pelanggannya yang mengatakan bahwa jam tangan benar original, tetapi juga dari jasa pengiriman yang ia percaya untuk mengantar barang dagangannya. 
Bagi Reza, segala sesuatu yang dikelola oleh negara tidak jarang dipandang 'bobrok' oleh masyarakat dan memiliki kinerja yang kurang begitu baik. Pandangan ini diperkuat ketika dirinya di Tiongkok untuk mengikuti program Au Pair ${ }^{2}$. Menurut Reza, dirinya melihat bahwa masyarakat Tiongkok juga lebih memilih menggunakan jasa pengiriman milik swasta atau luar negeri dibanding menggunakan jasa pengiriman milik negara. Hal tersebut dilatarbelakangi oleh pandangan yang sama bahwa jasa pengiriman yang dikelola oleh pemerintah Tiongkok memiliki kinerja yang tidak begitu bagus. Pandangan dan ketidakpercayaan Reza kepada instansi pemerintah ini berdampak pada pemilihan jasa pengiriman yang ia gunakan. Dirinya tidak mau reputasi toko online-nya hancur karena menggunakan jasa pengiriman yang menurutnya memiliki reputasi kurang baik. Meski begitu, Reza mengakui bahwa untuk pengiriman secara pribadi, dirinya memilih menggunakan jasa pengiriman Pos Indonesia dan mengaku belum pernah menemukan masalah dalam prosesnya. Meski begitu, dirinya tidak mau mengambil resiko karena menurutnya, bisa saja pelanggannya memiliki sentimen negatif juga dengan Pos Indonesia.

Sama halnya dengan Reza yang tidak pernah menemui masalah ketika menggunakan jasa pengiriman Pos Indonesia secara pribadi, Intan yang menjual bantal untuk dekorasi rumah ini juga mengaku bahwa setelah dirinya pindah menggunakan jasa pengiriman Pos Indonesia, proses pengiriman barangnya menjadi lebih nyaman dan worry less. Sebelum menggunakan jasa pengiriman Pos Indonesia, Intan lebih dulu menggunakan jasa pengiriman milik sebuah perusahaan swasta. Namun pengalaman kurang menyenangkan Intan alami ketika seorang pelanggannya mengatakan bahwa paket bantal yang dipesannya tidak sesuai dengan yang dibelinya. Paketnya rusak dan jumlah bantalnya kurang. Intan kemudian melakukan complaint kepada pihak jasa pengiriman tersebut namun Intan tidak pernah mendapat kejelasan bagaimana proses komplain tersebut berlanjut.

"Aku ingat banget packing empat bantal jadi satu, nggak pisah-pisah. Masa hilang dua, kan gak masuk akal banget. Berarti kan dibuka dong tanpa sepengetahuanku dan nggak di-pack lagi atau gimana, aku juga gak paham karena nggak dapat kejelasan. Sampai aku datang ke kantor pusat jasa pengiriman itu berkali-kali, tapi mereka [pegawai jasa pengiriman] hanya bilang 'akan kami proses, akan kami proses, blablabla..., tapi gak pernah berlanjut sampai sekarang. Bahkan mereka nggak ganti rugi sama sama sekali. Padahal aku baca di peraturan mereka, ada kompensasi untuk kasus seperti ini. Setelah itu mereka [pegawai jasa pengiriman] menyalahkan aku dengan alasan karena nggak diselotip full atau apalah itu. Bagiku tetap gak masuk akal karena hilangnya pun gak masuk akal" (Intan, wawancara tanggal 8 Januari 2018.)

Pengalaman buruk tersebut kemudian membawa Intan mencoba jasa pengiriman Pos Indonesia. Alasan Intan memilih Pos Indonesia masih tetap sama dengan alasan sebelumnya yaitu berdasarkan pengalaman dari teman-temannya sesama pedagang online. Intan mengaku sejak menggunakan Pos Indonesia, tidak pernah sekali pun mendapatkan pengalaman yang kurang menyenangkan seperti keluhan dari pelanggan, barang hilang

2 Au Pair merupakan kegiatan homestay di mana seseorang akan tinggal dengan keluarga asuh di negara tujuannya, mendapatkan berbagai fasilitas dari keluarga asuh, dengan timbal balik seseorang tersebut akan membantu keluarga asuhnya untuk mengurus anak dan membantu pekerjaan ringan rumah tangga. Au Pair banyak diikuti oleh mahasiswa atau fresh graduate dengan tujuan belajar bahasa asing, menambah uang saku, dan mencari beasiswa. 
atau rusak, dan proses pengantaran yang terlambat. Meski begitu, Intan mengatakan bahwa ada satu hal yang menjadi perhatiannya, yaitu perbandingan estimasi waktu sampai antara jasa pengiriman swasta yang sebelumnya ia gunakan dan jasa pengiriman Pos Indonesia, di mana keduanya memiliki waktu pengantaran yang berbeda berdasarkan pengalamannya menggunakan kedua jasa pengiriman tersebut. Menurutnya, Pos Indonesia cenderung menggunakan estimasi waktu terlama. Jika dijanjikan akan sampai dalam waktu 2-3 hari, maka barang akan sampai di hari ketiga. Penggunaan waktu estimasi dari Pos Indonesia ini menurut Intan merupakan konsekuensi yang harus didapatkan jika berurusan dengan layanan di bawah pemerintahan. Meski begitu, Intan tidak ambil pusing selama barangnya sampai ke pelanggan sesuai yang dijanjikan.

Pandangan terhadap instansi yang dikelola pemerintah tidak hanya dipengaruhi oleh pengalaman aktual yang dirasakan ketika berurusan langsung dengan sektor publik tersebut, tetapi dipengaruhi juga oleh kepercayaan terhadap pemerintahan yang memegang peranan penting dalam mengelolanya (Houston \& Howard Harding 2013; Marlowe 2004). Diskusi yang terbangun dengan Glen, Reza, dan Intan terkait dengan Pos Indonesia tidak terlepas dari status Pos Indonesia sebagai badan usaha milik pemerintah, di mana menurut mereka, pemerintah memiliki kinerja yang kurang memuaskan sehingga citra yang buruk menjadi lebih dominan. Ketika kepercayaan masyarakat terhadap pemerintah rendah, loyalitas terhadap layanan sektor publik yang dikelola pemerintah turut menjadi rendah dan kemudian mempengaruhi perilaku masyarakat terhadap layanan sektor publik tersebut sebagai bentuk protes dan ketidakpuasan mereka. Salah satunya adalah dengan tidak terlibat dengan sektor publik tersebut (Hetherington 1999; Hooghe et al. 2011). Hal ini dapat terlihat juga dari bagaimana Glen dan Reza menempatkan Pos Indonesia dalam proses pengiriman dagangan mereka, yaitu dengan melibatkan suara pelanggannya. Jika pelanggannya meminta menggunakan Pos Indonesia, maka mereka akan menggunakan Pos Indonesia karena bagi mereka, pelanggan adalah raja yang memiliki preferensinya masing-masing.

\section{Ongkir Murah dan Klasifikasi Pelanggan}

Salah satu yang membedakan aktivitas jual beli online - khususnya partial e-commerce - dengan jual beli secara konvensional adalah adanya tambahan biaya pengantaran yang dibayarkan kepada jasa pengiriman atau seringkali disebut dengan ongkos kirim. Biaya ongkos kirim - atau biasa disingkat menjadi ongkir - biasanya dibebankan kepada pelanggan daripada toko online. Kondisi ini membuat barang yang akan dibeli menjadi lebih mahal karena adanya biaya tambahan. Biaya akan semakin besar jika lokasi toko online jauh dari lokasi pelanggan. Biaya pengiriman ditentukan salah satunya oleh jarak yang ditempuh untuk pengantaran, harga barang yang dikirimkan - berkaitan dengan asuransi pengiriman - dan berat barang yang dikirim.

Bertini dan Wathieu (2008) menjelaskan bahwa konsumen cenderung lebih sensitif terhadap biaya sekunder di luar biaya produk atau jasa yang mereka beli dan menyebabkan konsumen berpikir dua kali untuk menyelesaikan pembelian atau malah membatalkannya. Hampir semua e-marketplace dan pedagang online menyadari bahwa ongkir ini menjadi salah satu musuh para konsumen sehingga tidak jarang kita temui promosi yang berkaitan dengan ongkir, seperti bebas biaya ongkir untuk area tertentu, gratis biaya ongkir untuk 
pembelian jumlah tertentu, dan diskon biaya ongkir jika menggunakan jasa pengiriman tertentu.

Seperti yang sudah sempat saya singgung, biaya ongkir salah satunya ditentukan dari berat barang yang akan dikirim. Semakin berat dan besar barang yang akan dikirim, maka akan semakin besar biaya ongkos kirimnya. Setiap jasa pengiriman memiliki standar masing-masing berkaitan dengan berat barang serta biaya ongkir, di mana yang biasa kita temui adalah pembulatan ke satu kilogram untuk berat barang sehingga konsumen akan tetap membayar berat barang satu kilogram meskipun berat barang yang akan dikirim kurang dari itu. Dibandingkan dengan jasa pengiriman pesaingnya, Pos Indonesia tidak menggunakan pembulatan berat ke satu kilogram melainkan hitungan per gram. Kebijakan ini tentu menguntungkan khususnya bagi mereka yang akan mengirimkan paket yang lebih ringan atau yang sangat berat karena tidak memakan biaya yang lebih besar.

Jika bicara soal ongkir, kelima informan saya sepakat bahwa Pos Indonesia merupakan jasa pengiriman dengan biaya jasa termurah. Mikael yang seringkali menerima orderan apparel (pakaian) dalam partai besar ini sudah menggunakan hampir seluruh jasa pengiriman yang tersedia dan mengakui bahwa dirinya akan merekomendasikan Pos Indonesia ke pelanggannya, khususnya pelanggan dengan jarak jauh. Senada dengan Mikael, Glen masih memegang prinsip bahwa Pos Indonesia sebagai perusahaan jasa pengiriman dengan harga murah dan masuk akal. Hal tersebut terlihat dari pelanggan toko online-nya yang berada di luar pulau Jawa yang cukup banyak yang memilih Pos Indonesia sebagai jasa pengirimannya.

Biaya jasa pengiriman Pos Indonesia yang tergolong murah ini ternyata menghadirkan pandangan tersendiri bagi para pedagang online ini. Glen dan Intan sepakat bahwa murahnya ongkos kirim Pos Indonesia ini cocok untuk mengirim barang berukuran kecil atau mengirim barang ke luar pulau Jawa, namun tidak cocok jika barang yang dibutuhkan harus sampai dengan cepat.

"Pos Indonesia itu aku lihatnya banyak [menjadi pilihan] ke luar [pulau] Jawa. Karena lebih murah dan cocok untuk kirim barang yang kecil-kecil" (Glen, wawancara tanggal 15 Desember 2017) .

"Kalau ke luar [pulau] Jawa itu lebih murah pakai Pos Indonesia dibanding [jasa pengiriman] yang lain. Apalagi kalau pesanannya di atas dua kilogram. Jadi di Shopee aku tetap masukin pilihan Pos Indonesia" (Intan, wawancara tanggal 8 Januari 2018).

Mikael juga mengatakan bahwa setiap jasa pengiriman memiliki budget tersendiri untuk operasionalnya, salah satunya dari harga ongkir yang kita bayarkan. Murahnya biaya yang didapatkan menurut ketiganya berimbas kepada kecepatan dalam pengiriman barang.

"Misal ada pelangganku beli barang dan minta barangnya dikirim pakai jasa pengiriman yang murah, terus aku saranin pakai Pos Indonesia, terus dia mengeluh barang yang dia beli sampainya telat. Ya, bukan salahku, dan bukan salah Pos Indonesianya juga. Pelangganku butuh kualitas baik dengan harga murah? Ya nggak ada. Harga murah ya harga murah. Jangan mengharapkan harga murah tapi pengen sampai cepat. Jasa pengiriman bekerja sesuai budget-nya. Budget mereka [jasa pengiriman] ya dari ongkos kirim itu" (Mikael, wawancara tanggal 27 Desember 2017). 
Berbeda dengan Mikael, Glen, dan Intan yang menggunakan Pos Indonesia untuk memberikan pilihan bagi pelanggan mereka, Reza memilih untuk tidak menggunakan Pos Indonesia. Salah satu alasannya adalah karena harga ongkir. "Ada uang ada barang", begitu prinsip Reza. Bagi Reza, harga ongkir yang murah dapat memberikan kesan murah pada toko online-nya. Dirinya tidak mau pelanggannya bertanya-tanya, mengapa Reza memilih jasa pengiriman yang murah, padahal uang yang dikeluarkan oleh pelanggannya untuk membeli jam tangan tersebut tidaklah sedikit (wawancara tanggal 3 Januari 2018). Berdasar pada pemikirannya tersebut, Reza hanya menggunakan satu jasa pengiriman saja yang merupakan jasa pengiriman dengan layanan sehari sampai dari salah satu perusahaan jasa pengiriman milik swasta. Meski untuk toko online-nya Reza tidak menggunakan jasa pengiriman Pos Indonesia, bagi kebutuhan pribadinya Reza memilih menggunakan Pos Indonesia. Selain karena ongkos kirim yang tidak mahal, layanan dari Pos Indonesia menurut Reza tidaklah mengecewakan. Meski begitu, pengalaman pribadinya tersebut tidak membuat Reza kemudian memilih Pos Indonesia. Hal ini kembali lagi sebagai upaya Reza untuk membangun reputasi toko online-nya.

Produk atau merek yang dipilih oleh pelanggan seringkali berfungsi sebagai simbol pendapatan dan sebagai bentuk komunikasi perbedaan kelas sosial, terutama status (Douglas dan Isherwood 1979). Bagi Reza, pemilihan jasa pengiriman yang 'memiliki kelas' merupakan hal penting bagi dirinya sebagai pedagang online dan juga bagi toko online-nya agar tidak dipandang rendah dan diremehkan oleh orang lain atau pelanggannya. Reza sebagai pribadi memang memilih menggunakan jasa pengiriman Pos Indonesia karena harganya yang murah sehingga ia tidak perlu mengeluarkan banyak biaya untuk ongkirnya. Bagi Reza, kebutuhan pribadinya tidak akan memengaruhi apapun terhadap toko onlinenya. Namun, penggunaan jasa pengiriman untuk toko online-nya akan berpengaruh terhadap pelanggannya dalam memandang toko online-nya. Reza yang menjual barang mewah yaitu jam tangan berharap bahwa keputusannya tidak menggunakan Pos Indonesia akan membentuk rasa percaya terhadap pelanggannya bahwa jam tangan yang dijualnya adalah jam tangan asli dan dalam pengirimannya akan diperlakukan dengan istimewa karena menggunakan jasa pengiriman dengan ongkos kirim yang mahal.

Meski seringkali digunakan sebagai indikator penentu, namun harga tidak menjadi faktor utama bagi konsumen untuk menentukan kualitas suatu produk atau jasa. Peran harga dapat menjadi sangat kecil sebagai penentu kualitas apabila terdapat value yang didapatkan konsumen dari menggunakan jasa atau produk tersebut (Zeithaml 1988). Meski dipandang mempengaruhi durasi pengiriman, namun Mikael, Glen, dan Intan sepakat bahwa menggunakan jasa pengiriman Pos Indonesia adalah sebuah cara untuk membangun hubungan dengan kelompok pelanggan tertentu, seperti pelanggan dengan pengiriman jarak jauh dan pelanggan dengan pembelian partai kecil.

\section{Minim Upaya dalam Beradaptasi dengan Zaman}

Jika melihat kembali ke sejarah lahirnya Pos Indonesia, tidak dapat dipungkiri bahwa Pos Indonesia merupakan perusahaan jasa pengiriman tertua di Indonesia saat ini. Usianya yang telah menginjak lebih dari dua setengah abad membuktikan bahwa Pos Indonesia mampu berhadapan dengan generasi yang terus berganti serta era yang terus berubah. Mulai dari berkirim surat, pager, SMS, online chatting, hingga e-commerce. Meski sudah 
menjadi pemain lama di industri logistik dan jasa pengiriman tertua di Indonesia, tidak dapat dipungkiri bahwa Pos Indonesia masih perlu kerja ekstra untuk dapat bersaing dengan para kompetitornya khususnya di era e-commerce seperti sekarang ini.

Berdasarkan survei yang dilakukan oleh Frontier Research untuk Top Brand Award di Indonesia, sejak 2016 hingga 2017 Pos Indonesia belum mampu menyaingi dua pesaing utamanya yaitu JNE pada urutan pertama dan TIKI di urutan kedua. Posisi Pos Indonesia di tiga besar kemudian disalip oleh pemain baru yaitu J\&T yang pada 2018 naik ke posisi dua sebagai jasa pengiriman terbaik sehingga Pos Indonesia harus turun ke posisi empat. Posisi Pos Indonesia di urutan keempat jasa pengiriman terbaik masih bertahan hingga survey terakhir di 2020, satu tingkat di atas DHL, jasa pengiriman milik Amerika yang menduduki posisi kelima. Lima tahun berselang, Pos Indonesia sebagai satu-satunya jasa pengiriman milik negara sekaligus tertua di Indonesia belum mampu menyaingi jasa pengiriman milik swasta lainnya sebagai jasa pengiriman terbaik di Indonesia.

Belum mampunya Pos Indonesia menyaingi jasa pengiriman swasta di era e-commerce seperti saat ini menurut Zaskia disebabkan oleh kurangnya usaha Pos Indonesia dalam beradaptasi dengan anak-anak muda yang menurutnya merupakan pemain dan pelaku utama dari e-commerce. Zaskia sebagai seorang personal shopper atau sering disebut juga dengan penyedia jastip ${ }^{4}$ melihat pelanggannya merupakan anak-anak muda yang menginginkan hal baru, unik, dan beda dari yang lainnya. Hal ini terlihat dari bagaimana pelanggannya meminta dirinya untuk membelikan barang-barang - khususnya fashion item - yang sedang naik daun atau viral di media sosial. Kesan "anak muda" ini menurutnya tidak tercermin dari Pos Indonesia yang sudah terlanjur terlabeli dengan perusahaan tua dengan fokus kerja di surat menyurat zaman dahulu kala. Zaskia mengibaratkan Pos Indonesia tidak ubahnya seperti manusia yang semakin tua maka geraknya akan semakin lamban dan tergantikan oleh generasi berikutnya. Keadaan tersebut yang membuat Zaskia lebih percaya kepada jasa pengiriman yang hadir di era berdagang online ketimbang jasa pengiriman yang hadir lebih dulu sebelum adanya kebiasaan jual beli melalui internet.

"Orang kan semakin tua semakin lambat. Menurutku, Pos Indonesia juga akan seperti itu, lambat laun [kinerja] akan semakin lambat dan diganti sama jasa pengiriman baru yang memang hadir di era yang baru [era e-commerce" (Zaskia, wawancara tanggal 15 Januari 2018).

Senada dengan pandangan Zaskia, Glen menyebut bahwa Pos Indonesia merupakan

3 Top Brand merupakan lembaga survei mandiri skala nasional yang melakukan survey kepada brand barang dan jasa di 15 kota besar di Indonesia dengan total responden sebanyak 12,000 orang. Top Brand akan memberikan penghargaan kepada brand barang dan jasa pilihan konsumen yaitu Top Brand Award dengan syarat brand tersebut memenuhi Top Brand Index (TBI) sebesar $10.0 \%$. TBI menggunakan tiga parameter sebagai ukurannya dan berdasarkan perilaku konsumen, yaitu 1) brand pertama yang disebut responden ketika mendengar kategori produk, 2) brand terakhir yang digunakan oleh responden/digunakan berulang kali, 3) brand yang akan digunakan oleh responden di masa mendatang (sumber: http:// www.topbrand-award.com/).

4 Jastip merupakan singkatan dari jasa titip di mana penyedia jastip membantu orang-orang untuk membeli barang sesuai pesanan yang berada di luar jangkauan orang tersebut dengan biaya jasa yang telah disepakati 
perusahaan jasa pengiriman yang old school atau ketinggalan zaman. Pandangannya terbentuk karena seringnya ia berinteraksi dengan pegawai Pos Indonesia yang menurutnya masih diisi dengan orang-orang tua sehingga ide yang muncul untuk melakukan adaptasi kepada para pemain e-commerce menjadi terkesan kuno dan lambat. Hal ini menurut Glen dapat dilihat dari kurangnya aktivitas Pos Indonesia di media sosial. Padahal, media sosial merupakan salah satu ruang para pemain e-commerce khususnya pedagang online dalam berinteraksi satu sama lain. Eksistensi Pos Indonesia di media sosial juga disinggung oleh Reza yang berpandangan bahwa Pos Indonesia seharusnya memiliki strategi adaptasi dengan netizen ${ }^{5}$ yang mirip dengan perusahaan Go-Jek, yaitu membentuk komunitas yang kuat dalam ruang virtual salah satunya Instagram. Segala yang berkaitan dengan Go-Jek di mata Reza merupakan konten yang bersifat viralable atau dengan mudah tersebar dan diketahui oleh masyarakat secara luas. Secara tidak langsung, hal tersebut menjadi sebuah ajang pengenalan Go-Jek kepada netizen dan menimbulkan rasa ingin tahu lebih jauh terkait dengan Go-Jek. Sependapat dengan Reza, Mikael menjadikan Go-Jek sebagai perbandingan dengan Pos Indonesia dalam aspek perkembangan zaman, khususnya dalam memanfaatkan internet dan dunia maya untuk membentuk awareness terkait layanan Pos Indonesia.

Beradaptasi dengan zaman menjadi hal yang sangat penting bagi perusahaan untuk mempertahankan eksistensi mereka agar terus dapat bersaing meski terjadi pergantian generasi. Salah satu bentuk adaptasinya adalah dengan terus memodernisasi citra sesuai dengan target segmen generasi lebih muda yang akan terus memiliki daya beli lebih tinggi (Hameide 2011). Pandangan akan jasa pengiriman Pos Indonesia yang kurang mampu beradaptasi dengan perkembangan zaman tidak terlepas dari perbandingan yang dilakukan oleh Zaskia, Glen, Reza, dan Mikael dengan perusahaan-perusahaan sejenis yang memiliki layanan jasa yang sama yaitu jasa pengiriman barang atau paket. Mereka melihat bahwa terdapat jasa pengiriman lain yang lebih mampu memanfaatkan teknologi yang tersedia seperti media sosial dalam menanamkan ingatan terkait jasa pengiriman tersebut seperti melalui iklan atau pembuatan konten yang bersifat 'viralable'. Melalui perbandingan tersebut, informan melihat bahwa seharusnya Pos Indonesia melakukan hal yang sama agar terus bertahan sebagai pilihan masyarakat khususnya pedagang online dan tidak tenggelam akibat gagal beradaptasi dengan perkembangan zaman.

\section{Menyimpulkan Pos Indonesia Lewat Kacamata Pedagang Online}

Hadirnya e-commerce memberikan ruang yang begitu luas bagi masyarakat untuk berdagang. Orang-orang dapat menjajakan dagangannya tanpa harus memiliki lapak di mall atau pasar karena hadirnya ruang-ruang virtual dengan cakupan target konsumen yang lebih luas. Begitu juga dengan pelanggan yang memiliki lebih banyak pilihan serta kemudahan dalam berbelanja tanpa perlu repot keluar rumah. Semua dapat dilakukan hanya melalui layar gawai. Baik melalui e-marketplace atau media sosial, pedagang dan pembeli online terpisah oleh jarak yang begitu luas. Jarak ini kemudian menciptakan peluang khususnya bagi perusahaan jasa pengiriman yang kemudian banyak hadir menjadi

$5 \quad$ Gabungan dari kata 'internet' dan 'citizen', digunakan untuk menyebut kelompok masyarakat yang aktif di internet salah satunya media sosial. 
perantara antara pedagang dan pembeli dalam mengantarkan barang yang diperjualbelikan. Kini masyarakat memiliki banyak pilihan jasa pengiriman, mulai dari yang menawarkan layanan sehari hingga layanan antar jemput paket sehingga baik pedagang dan pembeli tidak perlu repot keluar rumah.

Pos Indonesia adalah salah satu perusahaan jasa pengiriman yang hadir menawarkan segala fasilitas dan layanan. Di usianya yang sudah mencapai dua setengah abad, Pos Indonesia telah memiliki hampir seratus persen cabang hingga di tingkat kecamatan, membuat Pos Indonesia menjadi satu-satunya jasa pengiriman dengan area kerja terluas. Pos Indonesia yang dahulu lebih dikenal dengan jawatan surat-menyurat kini tengah memfokuskan praktek kerjanya dalam pengiriman paket sebagai salah satu bentuk adaptasi dengan era e-commerce. Namun, menjanjikannya pasar bagi industri jasa pengiriman di Indonesia membuat Pos Indonesia kini harus menghadapi persaingan ketat di antara perusahaan-perusahaan jasa pengiriman baik dari dalam maupun luar negeri yang mencoba peruntungannya di Indonesia.

Kelima pedagang online dalam artikel ini memiliki pengalaman masing-masing dengan Pos Indonesia yang membentuk pandangan mereka terhadap jasa pengiriman dari perusahaan milik negara tersebut. Berdasarkan pengalaman mereka, Pos Indonesia memiliki kekurangan dan kelebihan yang dipengaruhi oleh tiga hal, yaitu 1) Pos Indonesia dan statusnya sebagai perusahaan milik negara, di mana kinerja dan performa yang kurang baik merupakan ciri khas layanan publik milik negara. Anggapan tersebut turut mempengaruhi pandangan kelima informan terhadap Pos Indonesia melalui pengalaman mereka yang kurang menyenangkan berkaitan dengan estimasi waktu sampai yang tidak sesuai dan kinerja pegawai yang tidak profesional; 2) tarif ongkos kirim yang murah, di mana di satu sisi harga ongkos kirim yang murah dianggap mampu menarik pelanggan khususnya yang berada di luar pulau Jawa, namun harga ongkos kirim yang murah tersebut juga menjadi tolak ukur kinerja dari Pos Indonesia yang dipandang lebih cocok untuk mengirim paket berisi barang dengan nilai murah pula, berukuran kecil, tidak terburuterburu untuk sampai tujuan; dan 3) perkembangan zaman, di mana Pos Indonesia dipandang sebagai jasa pengiriman yang ketinggalan zaman dan belum mampu beradaptasi dengan perkembangan zaman akibat kurangnya kehadiran Pos Indonesia di dunia maya yang merupakan ruang kerja dari pedagang online. Pandangan ini juga terbentuk dari perbandingan yang dilakukan pedagang online dengan jasa pengiriman lain yang menurut mereka lebih mampu beradaptasi dengan era internet melalui pemanfaatan teknologi informasi.

Ketika era berganti, preferensi masyarakat juga turut mengikuti. Hadirnya e-commerce turut membentuk kebiasaan baru yaitu jual-beli online yang memberikan hawa segar bagi industri jasa pengiriman, tidak terkecuali Pos Indonesia. Meski masih memiliki konsumen setia, jasa pengiriman tertua milik negeri ini masih perlu kerja ekstra untuk dapat terus menggaet konsumen dari generasi muda, khususnya di era e-commerce. Di samping pandangan pedagang online terhadap jasa pengiriman Pos Indonesia, pelanggan toko online memiliki peran penting dalam menentukan jasa pengiriman yang akan digunakan. Jasa pengiriman tidak hanya berperan sebagai penghubung antara pedagang online dengan pembeli online dalam mengantar barang yang dibeli, tetapi juga menjadi pengikat kepercayaan antara keduanya di tengah kegiatan berdagang online yang memungkinkan terjadinya pertukaran jual-beli tanpa tatap muka. Keterlibatan pelanggan 
toko online dengan jasa pengiriman dapat menjadi ide penelitian lebih lanjut yang menarik untuk dikembangkan guna menyempurnakan penelitian terkait Pos Indonesia. Dengan demikian, Pos Indonesia dapat memiliki gambaran lebih mendalam mengenai kelompok penggunanya yang lain dalam memanfaatkan layanan Pos Indonesia.

\section{Referensi}

Ahmad, S. 2002. "Service Failures and Customer Defection: A Closer Look at Online Shopping Experiences”. Managing Service Quality: An International Journal, Vol. 12, Iss. 1, pp. 19-29.

Bell, D. 2002. An Introduction to Cybercultures. London \& New York: Routledge.

Bertini, M. and Wathieu, L. 2008. "Research note-Attention Arousal Through Price Partitioning”. Marketing Science, Vol. 27, pp. 236-246.

Douglas, M dan Isherwood, B. 1979. The World of Goods: Towards An Anthropology of Consumption. London \& New York: Routledge.

Ehmke, J. F. dan Mattfeld, D.C. 2012. "Vehicle Routing for Attended Home Delivery in City Logistics". Procedia - Social and Behavioral Sciences, Vol. 39, pp. 622-632

Freischlad, N. 2016. "Google: Indonesia Will Dominate Southeast Asian E-commerce". Diakses pada 28 Juni 2021. http://www.techinasia.com/google-temasek-ecommercedata-indonesia/

Hameide, K. K. 2011. Fashion Branding Unraveled. New York \& London: Fairchild Books. Hetherington, M. J. 1999. "The effect of political trust on the presidential vote, 1968-1996". American Political Science Review, Vol. 93, pp. 311-326.

Hooghe, M., Mariën, S., \& Pauwels, T. 2011. "Where do distrusting voters turn to if there is no viable exit or voice option? the impact of political trust on electoral behaviour in the Belgian regional elections of June, 2009". Government and Opposition, Vol. 46, pp. 245-273

Houston, D.J. \& Howard Harding, L. 2013. "Public Trust In Government Administrators". Public Integrity, Vol. 16, pp. 53-76.

Marlowe, J. 2004. "Part of the solution or cogs in the system? The origins and consequences of trust in public administrators". Public Integrity, Vol. 6, pp. 93-113.

Miller, D, et al. 2016. Why We Post: How the World Changed Social Media. London: UCL Press.

Pos Indonesia. 2021. "Sejarah Pos Indonesia”. Diakses pada 8 Juni 2021. https://www. posindonesia.co.id/en/content/sejarah-pos

Turban, E, et al. 2016. Social Commerce: Marketing, Technology, \& Management. Swiss: Springer.

Turban, E, et al. 2017. Introduction to Electronic Commerce and Social Commerce: Fourth Edition. Swiss: Springer.

Zeithaml, V.A. 1988. "Consumer Perceptions of Price, Quality, and Value: A Means-End Model and Synthesis of Evidence." Journal of Marketing, Vol. 52, pp. 12-17. 